This item was submitted to Loughborough's Research Repository by the author.

Items in Figshare are protected by copyright, with all rights reserved, unless otherwise indicated.

\title{
Strategic innovation through outsourcing: the role of relational and contractual governance
}

PLEASE CITE THE PUBLISHED VERSION

http://dx.doi.org/10.1016/j.jsis.2015.08.001

PUBLISHER

(C) Elsevier

VERSION

AM (Accepted Manuscript)

\section{PUBLISHER STATEMENT}

This work is made available according to the conditions of the Creative Commons Attribution-NonCommercialNoDerivatives 4.0 International (CC BY-NC-ND 4.0) licence. Full details of this licence are available at: https://creativecommons.org/licenses/by-nc-nd/4.0/

\section{LICENCE}

CC BY-NC-ND 4.0

\section{REPOSITORY RECORD}

Oshri, Ilan, Julia Kotlarsky, and Alexandra Gerbasi. 2015. "Strategic Innovation Through Outsourcing: The Role of Relational and Contractual Governance”. Loughborough University. https://hdl.handle.net/2134/19761. 
Final version, accepted for publication in Journal of Strategic Information Systems. To appear in volume 21 issue 3 (2015)

\title{
Strategic Innovation Through Outsourcing: The Role of Relational and Contractual Governance
}

\author{
Ilan Oshri ${ }^{\text {a, }}$, Julia Kotlarsky ${ }^{\text {b }}$, Alexandra Gerbasi ${ }^{\text {c }}$ \\ ${ }^{a}$ Centre for Global Sourcing and Services, Loughborough School of Business and Economics, \\ Loughborough LE22 3TU, United Kingdom \\ ${ }^{\mathrm{b}}$ Aston Business School, Aston University, Aston Triangle, Birmingham B4 7ET, United Kingdom \\ ${ }^{\mathrm{c}}$ Grenoble Ecole de Management, 2 rue Pierre Sémard, 38000 Grenoble, France
}

\begin{abstract}
There is growing evidence that client firms expect outsourcing suppliers to transform their business. Indeed, most outsourcing suppliers have delivered IT operational and business process innovation to client firms; however, achieving strategic innovation through outsourcing has been perceived to be far more challenging. Building on the growing interest in the IS outsourcing literature, this paper seeks to advance our understanding of the role that relational and contractual governance plays in achieving strategic innovation through outsourcing. We hypothesized and tested empirically the relationship between the quality of client-supplier relationships and the likelihood of achieving strategic innovation, and the interaction effect of different contract types, such as fixed-price, time and materials, partnership and their combinations. Results from a pan-European survey of 248 large firms suggest that high-quality relationships between clients and suppliers may indeed help achieve strategic innovation through outsourcing. However, within the spectrum of various outsourcing contracts, only the partnership contract, when included in the client contract portfolio alongside either fixed-price, time and materials or their combination, presents a significant positive effect on relational governance and is likely to strengthen the positive effect of the quality of client-supplier relationships on strategic innovation.
\end{abstract}

Keywords: Outsourcing, strategic innovation, quality of client-supplier relationship, fixed-price contract, time and materials contract, joint venture contract, client contract portfolio, survey

\footnotetext{
* Corresponding author. Tel.: +44 1509223115.

Email addresses: i.oshri@lboro.ac.uk (I. Oshri), j.kotlarsky@aston.ac.uk (J. Kotlarsky), alexandra.gerbasi@grenoble-em.com (A. Gerbasi).
} 


\section{INTRODUCTION}

The last fifteen years have witnessed significant growth in the outsourcing industry (Oshri et al. 2015). While the early years of Information Technology (IT) and business process outsourcing (BPO) were mainly characterized by a quest for costs savings (Loh and Venkatraman 1992; Lacity and Hirschheim 1993) and a focus on core competences (Quinn and Hilmer 1994), recent evidence suggests that client firms now seek to achieve added value from outsourcing by accessing suppliers’ competences (e.g. Dyer and Nobeoka 2000; Quinn 2000; Whitley and Willcocks 2011). Mol (2005: 571) argues that "firms are increasingly relying on partnering relationships with outside suppliers that can act as an effective substitute to the internal generation of knowledge and innovation”. Similarly, Linder et al. (2003) and Weeks and Feeny (2008) argue that client firms rely on external suppliers in the search for new ideas. More recently, accepting that innovation is outsourced and offshored, Lewin et al. (2009) studied the determinants driving firms to offshore innovations only to conclude that firms have been entering a global race for talent in which solutions will be sought wherever skills are available. Such observations suggest that innovation may be considered as one of the possible outcomes of outsourcing engagements.

Indeed, several recent studies have examined the practices through which innovation can be achieved in outsourcing settings (Weeks and Feeny 2008; Whitley and Willcocks 2011; Lacity and Willcocks 2014). Weeks and Feeny (2008) offer a taxonomy of forms of innovation through outsourcing that distinguishes between IT operational and business process innovations, and strategic innovations. The former corresponds with incremental forms of innovation (Dewar and Dutton 1986), while the latter matches the definition of radical innovation (Droege et al. 2009). Defined as ways to “significantly enhance the firm's product or service offerings for existing target customers, or enable the firm to enter new markets” (Weeks and Feeny 2008: 131), strategic innovations have been traditionally perceived to be more challenging to achieve (Weeks and Feeny 2008) and therefore will be the focus of this study. Strategic innovation requires significant product or service development and its success can be challenged by lack 
of cooperation, low levels of trust and information asymmetry between the supplier and client (Weeks and Feeny 2008). Similarly, the lack of appropriate incentives for both client and supplier may inhibit the sides from developing collaborative innovation through outsourcing (Lacity and Willcocks 2014). The limited literature on innovation in the outsourcing context has persistently highlighted the key role that relational governance plays in creating favourable conditions for strategic innovation through outsourcing (Whitley and Willcocks 2011; Weeks and Feeny 2008). We concur with such observations; however, we seek to advance and contribute to the Information Systems (IS) outsourcing literature by examining the role that relational and contractual governance plays in fostering strategic innovation through outsourcing. In particular, we seek to verify whether high-quality relationships between clients and suppliers do lead to strategic innovation, and whether certain contract types positively or negatively affect the impact of highquality client-supplier relationships on the ability to achieve strategic innovation. Relational governance will be examined in this study as the quality of the client and supplier relationships (Lacity et al. 2010), while contractual governance will be explored through three contract types commonly used in outsourcing engagements: fixed-price, time and materials (Gopal et al. 2003; Gefen et al. 2008) and partnership-based (Willcocks and Choi 1995; Dibbern et al. 2004), and the combinations of these contract types. This research relies on a pan-European cross-industry survey that included representatives of 248 firms that are buyers of IT and business process outsourcing services. Respondents were senior managers involved in the execution of outsourcing projects or programmes who were selected in accordance to the “key informant” methodology (e.g. Goo et al. 2008).

The contributions of this study are twofold. First, our paper is one of the early attempts to shed light on the link between a governance approach and strategic innovation through outsourcing. In this regard, our empirical results confirm a positive effect of the client-supplier relationships on the likelihood of achieving strategic innovation. Second, this study shows that the interaction of contractual governance with relational governance is central to achieving strategic innovation through outsourcing. We found that a partnership contract, when included in the client contract portfolio alongside a fixed-price or time and 
materials contract magnifies the positive effect of the client-supplier relationships on the possibility to achieve strategic innovation, but no effect for fixed-price and time and materials contracts, as stand-alone contracts.

The rest of the paper is organized as follows: first the literature on innovation in the context of strategic IT and business process outsourcing is reviewed; then we theorize about the role of relational and contractual governance in achieving strategic innovation. This is followed by an explanation of methods and results and a discussion of our findings in the light of the existing literature. We conclude with theoretical and practical contributions.

\section{THEORETICAL BACKGROUND AND HYPOTHESES}

\section{Strategic Innovation in the Context of IT and Business Process Outsourcing}

The outsourcing of IT and business processes has been recognized as one of the risk factors that may lead to the loss of innovative capabilities inside a client's firm (Weeks and Feeny 2008). Past studies, however, have persistently anticipated that outsourcing will deliver new ideas and value to both business operations and strategic objectives (Lacity and Hirschheim 1993; Lacity et al. 2010). Despite the above risk, innovation is one of the potential promises of outsourcing; however, one which is poorly understood. For example, studies that discuss innovation in the context of IS outsourcing have mainly relied on a small number of cases or instances, shedding little light about the governance structures affecting innovation (e.g. Levina and Vaast 2008; Weeks and Feeny 2008; Whitley and Willcocks 2011; Lacity and Willcocks 2013). Further, in the few studies in the IS outsourcing literature that have attempted to model innovations, this concept was perceived to be an independent variable (e.g. Kishore et al. 2003) rather than a possible outcome of an outsourcing project (Lacity et al. 2010).

The innovation literature distinguishes between various types of innovations. For example, numerous studies on innovation have adopted the concepts of incremental and radical innovations (e.g. Ettlie et al. 
1984; Dewar and Dutton 1986; Malhotra et al. 2001) or exploitative and exploratory innovations (e.g. Jansen et al. 2006). In the IS literature, Weeks and Feeny (2008) offer a helpful taxonomy of innovation that could be achieved through outsourcing. They distinguish between IT operational innovation, business process innovation and strategic innovation. Indeed, the vast majority of firms seeking innovation through outsourcing engagements have reported achieving IT operational and business process innovations (Weeks and Feeny 2008; Lacity and Willcocks 2013; Whitley and Willcocks 2011). Such innovations are achieved when the supplier introduces technology changes that do not impact firm-specific business processes (IT operational) or alters how the business operates in some important way (business process) (Weeks and Feeny 2008: 131). However, these studies report that client firms struggle to achieve strategic innovation through outsourcing engagements. Lacity et al. (2010) confirm the emphasis on IT operational and business process innovations through outsourcing engagements by highlighting that the main drivers to outsource include improvements in processes and services (DiRomualdo and Gurbaxani 1998), achieving change (Linder 2004) and improvements of the delivery time (Khan and Fitzgerald 2004). Yet, recent studies suggest that, while such improvements are desired in outsourcing engagements, client firms seek ways to benefit from transformative innovations that improve business performance with existing clients or enable the firm to enter new markets (Weeks and Feeny 2008; Whitley and Willcocks 2011; Lacity and Willcocks 2014). Lacity et al. (2010: 406) conclude that "truly strategic reasons for outsourcing IT have been relatively under-studied”. Consequently, strategic innovation is one of the key challenges firms face in general (McDermott and O’Connor 2002) and in the context of outsourcing in particular (Weeks and Feeny 2008), and therefore will be the focus of this study.

Examples of strategic supplier-led innovations include (i) the social media marketing platform that Infosys developed and implemented for Diageo ${ }^{1}$, and (ii) the supply chain system that IBM developed

\footnotetext{
${ }^{1}$ Infosys developed and implemented a marketing platform for Diageo (a global premium drinks company) that enabled Diageo to centrally manage brands through multiple social media channels, such as Facebook, Twitter and others (radical innovation in Diageo's marketing and brand management approaches, their core growth strategy). See press release: www.infosys.com/industries/consumer-packaged-goods/case-studies/Pages/new-digital-consumer-connections.aspx .
} 
(with Vodafone) for Novartis in order to deliver anti-malaria medication to remote locations ${ }^{2}$. Such strategic innovations are not necessarily captured in the outsourcing contract, though they tend to emerge over time through the development of a high-quality relationship between the client and the supplier in an ongoing outsourcing arrangement, such as in the case of IBM and Novartis, as well as through various contractual arrangements that incentivize the supplier to innovate for the client (Lacity and Willcocks 2014). As IS research weights the contribution of either contractual or relational governance to outsourcing performance, several studies revealed that contractual governance in fact interacts with relational governance. For example, Goo and Huang (2008) found out that well-structured Service Level Agreements (SLAs) have a positive influence on the various aspects of relational governance in IT outsourcing engagements. Further, numerous studies supported opposing views debating whether relational governance and contractual governance act as complements or substitutes (e.g. Poppo and Zenger 2002; Carson et al. 2006; Goo et al. 2009; Tiwana 2010). Inspired by this debate, a recent study by Huber et al. (2013) has demonstrated how relational and contractual governance act as complementary elements as well as substitution at different points during an outsourcing engagement.

\section{The Role of Relational and Contractual Governance in Achieving Strategic Innovation}

There is a general perception in the literature that high-quality client-supplier relationships improve outsourcing outcomes (Kishore et al. 2003; Whitley and Willcocks 2011). In this regard, client-supplier relationships represent the connections between staff from the supplier and client side that result in information and knowledge exchanges (Lee and Kim 1999; Kishore et al. 2003; Lacity et al. 2010). Jansen et al. (2006: 1663) explain that such relationships between people comprise a more voluntary mode of coordination than hierarchical structure. Client-supplier relationships are often manifested through the examination of the effectiveness of knowledge transfer (Tsai and Ghoshal 1998), the impact of cultural distance (e.g. Lee 2001; Rottman and Lacity 2006) and the degree of trust (e.g. Dibbern et al.

\footnotetext{
${ }^{2}$ See press release: www-03.ibm.com/press/us/en/pressrelease/29022.wss and www.malaria.novartis.com/innovation/sms-forlife/
} 
2008). In the specific context of strategic innovation through outsourcing, studies providing case-based evidence suggested a positive link between high-quality client-supplier relationships and the likelihood of achieving strategic innovation. For example, Weeks and Feeny (2008) argue that the relationship between the client and supplier will become instrumental in building the supplier's business process design (the learning capability of the supplier) and client-industry knowledge (the supplier's pool of business solutions), both imperative capabilities for the supplier in its attempt to deliver strategic innovations for the client (Kern et al. 2002; Kishore et al. 2003; Koh et al. 2004; Moon et al. 2010). In this regard, we anticipate that high-quality relationships will assist the supplier in gaining knowledge about the client's business and improve the supplier's ability to offer the client strategic innovation. Thus, we hypothesize the following:

H1: There is a positive relationship between the quality of client-supplier relationships and the likelihood of achieving strategic innovation.

While high-quality client-supplier relationships are likely to result in strategic innovation, the contract type applied in the outsourcing engagement may have an effect on the quality of the client-supplier relationships. Indeed, various studies suggested that contractual and relational governance act as either complementary or substitute to each other (Tiwana 2010) hinting at the effect, either positive or negative, of contractual elements on the quality of the client-supplier relationships (Goo et al. 2009). We therefore first discuss how the use of three contract types (i.e. fixed-price, time and materials and joint venture with profit sharing) as stand-alone contracts influence the positive effect of the quality of the client-supplier relationships on the likelihood of achieving strategic innovation. We then explore how the use of different client contract portfolios (each including combinations of different contract types) moderate the effect of the quality of the client-supplier relationships on strategic innovation.

A fixed-price contract may weaken the positive effect of the quality of client-supplier relationships on the likelihood of achieving strategic innovation. Consider the following example: A supplier is requested to 
develop a new supply chain system for their client to improve the delivery of anti-malaria medication in rural areas in Africa. While the supplier is likely to deploy its best resources and people to minimize the risk involved in a fixed-price contract (Gopal and Koka 2012), it will still be rather challenging for the supplier to account for all expected costs of the development effort upfront as well as compute and include unforeseen technical and managerial challenges involved in developing and implementing this strategic innovation. Such a fixed-price outsourcing contract that has scope for (or requirement of) delivering innovation is very likely to be incomplete, requiring the parties to adjust it whenever expectations or supplier's profitability have not been met (e.g. if a supplier is likely to endure significant additional efforts to deliver strategic innovations). A supplier may mitigate this risk of endangering its profitability if the parties agree to mutually adjust their obligations, expectations and interpretation of the fixed-price contractual term in what Gopal and Koka (2012) coined "relational flexibility”. However, unlike in IT operational or business process innovations (Weeks and Feeny 2008) where there is limited uncertainty about the costs involved in implementing new technology or a new change programme, thus a limited number of adjustments in the fixed-price contract, in a strategic innovation project the client and supplier will face a high degree of uncertainty (Dey et al. 2010; Dewar and Dutton 1986; McDermott and O’Connor 2002) requiring them to frequently adjust the contract. The likely result is a risk imbalance between the parties in favour of the client firm and a potential opportunism by the client. Consequently, opportunistic behaviour on the client's side in such a situation is likely to erode the positive relational effect on the ability to achieve strategic innovation.

Under a time and materials contract, the supplier's risks are minimized as any personnel and materials costs incurred by the supplier will be charged to the client (Gopal and Koka 2010). However, as the development of the supply chain system under a time and materials contract does not pose a significant financial risk for the supplier, it is likely that the supplier will place their best resources and people on other projects where higher financial risk fixed-price contracts are used (Gopal and Koka 2012). Even if a client attempts to specify the skills of the supplier's personnel required to work on delivering the strategic 
innovation initiative, such skills will be difficult to verify, and project staffing can always be manipulated by the supplier as the project progresses (Gopal and Koka 2012), for instance by moving highly qualified staff to higher risk projects. Consequently, we posit that there is a risk of exercising opportunism by the supplier that is likely to negatively affect outcomes of the strategic innovation project by staffing the project with less qualified personnel (Krishnan et al. 2000), hence negatively affecting the quality of the relationship between the parties. On the other hand, it is possible that a supplier engaged in the development of a supply chain system under a time and materials contract will seek opportunities to extend the initial scope of the project by accepting the client's requests for additional functionality (Bajari and Tadelis 2001), thus improving its project revenues (Gopal and Koka 2012). The materialization of such opportunity to extend the scope of the strategic innovation project will be subject to the client's satisfaction with the already delivered components in terms of time, cost and quality (Gopal and Koka 2012). Therefore, the supplier is likely to restrain the degree of opportunism exercised over the client, by staffing with qualified personnel and being responsive to changes in the scope of the project, in order to increase the likelihood of greater revenues from the strategic innovation project, thus ensuring positive relationships between the parties. A time and materials contract will therefore influence, either in a positive or negative manner, the effect of the quality of client-supplier relationships on the likelihood of achieving strategic innovation.

The few IS studies on innovation in service outsourcing hint at the possibility that a joint venture contract $^{3}$ may strengthen the positive effect of the quality of client-supplier relationships on the likelihood of achieving innovation (Lacity and Willcocks 2014). Such observations have also been made in the manufacturing context in which it was claimed that "proximity to potential partners such as suppliers [...] significantly and positively influences innovation” (Becheikh et al. 2006: 658) by

\footnotetext{
${ }^{3}$ A joint venture contract is a partnership type of contract that defines how client and supplier firms contribute resources to the new venture and states how gains (i.e. profits or savings) will be shared. The partners outline the mission and objectives for the joint venture, including the provision of funding, initial physical assets, intellectual capital, staff members, and management capabilities (Oshri et al. 2015). We use terms partnership and joint venture (with gainsharing) interchangeably throughout the paper referring to the same type of contract.
} 
improving the transfer of tacit knowledge sharing, developing trust and social capital with partners and reducing communication costs. Providing a rationale for the joint venture contract in IT outsourcing, DiRomualdo and Gurbaxani (1998: 76) claim that "sharing the costs and risks of commercialization with outsourcing partners can help maximize return on IT investments”. It flows from the above that joint venture contracts are likely to enhance the relational effect by deflating the risk of opportunism between the parties; placing the partners on similar grounds in terms of the risks that they take in contributing resources to the venture; and incentivizing the parties to collaborate as a motivator to benefit from the venture gains.

When a client firm uses two or more contract types, we talk about client contract portfolios, each comprising a different combination of contract types ${ }^{4}$. It is important to note that in any portfolio, different contract types could be used with the same supplier or with different suppliers. Therefore in this paper we highlight two possible scenarios. The first one (scenario 1) refers to portfolios that use different contract types with a single supplier, for example an outsourcing engagement in which joint venture with a gainsharing scheme is used alongside a fixed-price contract (Overby 2012). Such a portfolio "packs the most punch because it promises to increase the provider's revenue as well as the client's performance” (Lacity and Willcocks 2014: 78). It may deflate the risk of opportunism on behalf of either the supplier or the client and would motivate the parties to seek opportunities to maximize returns through collaboration and joint objectives (Overby 2012).

The second possible scenario (scenario 2) refers to client contract portfolios that include various contract types with different suppliers. For example, a client firm may set up a joint venture contract with one supplier while using a fixed-price contract with another. In such a client contract portfolio scenario there can be different degrees of (or no) interactions between client teams involved in different outsourcing engagements to suggest that the client firm may benefit from this client contract portfolio in terms of

\footnotetext{
${ }^{4}$ In our study, three contract types resulted in four possible client contract portfolios: fixed-price, time and materials and joint venture; fixed-price and joint venture; time and materials and joint venture; fixed-price and time and materials.
} 
strategic innovation. As it is difficult to provide a strong a priori justification about how different client contract portfolios moderate the effect of the quality of client-supplier relationships on the likelihood of achieving strategic innovation, in our research, we explore this effect.

Consequently, based on the above discussion of contract types and contract portfolios we hypothesize the following:

H2: A stand-alone contract (fixed-price, time and materials or joint venture with profit sharing) and any client contract portfolio (i.e. a combination of different contract types with a single or more suppliers) influence the positive effect of the quality of client-supplier relationships on the likelihood of achieving strategic innovation.

Our theoretical model that depicts hypotheses H1 and H2 is outlined in Figure 1.

Figure 1: Theoretical model

\section{Client Contract Type/Portfolio}

As a stand-alone or as a combination of:

- Fixed-price contract

- Time and materials contract

- Joint venture with profit sharing contract

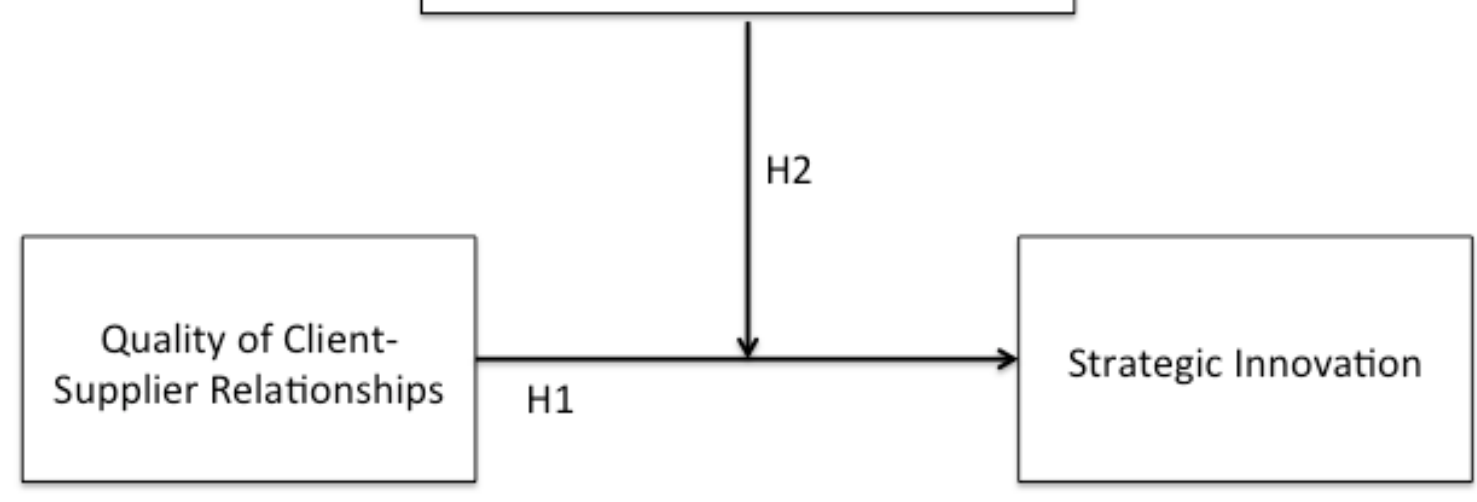




\section{METHODS}

\section{Data Collection}

We conducted a cross-industry survey of major European client firms from financial services, manufacturing, logistics, retail, utilities, telecom and other sectors. The data collection took place in late 2010. Senior managers at the client firms with extensive experience in outsourcing engagements for their firms were asked to respond to a survey regarding the quality of the relationships between their firm (unit of analysis) and their IT and business process outsourcing suppliers. This study applied a "key informant" methodology for data collection (Kumar et al. 1993; Segars and Grover 1998; Goo et al. 2008). To ensure that respondents were involved in major decisions regarding outsourcing in their organizations, and in the governance of outsourcing arrangements, a set of screening questions were included as part of the survey. Some of the dimensions examined in the screening questions were the role of the respondent within the firm, his or her involvement in outsourcing decision-making (unit, national, global and/or executive levels), and different types of contracts he or she managed. Over 2000 firms were initially contacted, and 248 fully completed the survey instrument, resulting in a response rate of over $10 \%$. Based on the data, there was not a significant difference between the demographic characteristics of firms that responded and those that did not.

To minimize potential biases, the respondents were assured that their responses and identities would remain confidential and that only aggregate information would be published. A “don’t know” response category was added to each question to minimize the risk of obtaining inaccurate responses from participants who did not know the answers to certain questions.

Overall the respondents represented a diversity of firms across multiple industries, regions, revenues and functions outsourced. In addition, those individuals who completed the survey for their firm tended to represent a high level of decision-making in the firm, over 74\% represented their function at the global level. For a full description of the firms, please see Table 1. 
Table 1: Description of the sample

\begin{tabular}{|c|c|c|c|}
\hline \multicolumn{4}{|c|}{ Description of the Firms } \\
\hline \multirow{7}{*}{ Country } & & Frequency & Percentage \\
\hline & Benelux & 25 & $10.08 \%$ \\
\hline & France & 24 & $9.68 \%$ \\
\hline & Germany & 25 & $10.08 \%$ \\
\hline & Nordics & 24 & $9.68 \%$ \\
\hline & Switzerland & 25 & $10.08 \%$ \\
\hline & United Kingdom & 125 & $50.40 \%$ \\
\hline \multirow{3}{*}{ Firm Revenue } & \$500 million - \$1000 million & 120 & $48.39 \%$ \\
\hline & \$1000 million - \$5000 million & 65 & $26.21 \%$ \\
\hline & More than \$5000 million & 63 & $25.40 \%$ \\
\hline \multirow{6}{*}{ Firm Sector } & Banking & 46 & $18.55 \%$ \\
\hline & Insurance & 36 & $14.52 \%$ \\
\hline & Internet media & 39 & $15.73 \%$ \\
\hline & Manufacturing & 47 & $18.95 \%$ \\
\hline & Retail & 42 & $16.94 \%$ \\
\hline & Telecommunications & 38 & $15.32 \%$ \\
\hline \multirow{3}{*}{$\begin{array}{l}\text { What Does the Firm } \\
\text { Outsource* }\end{array}$} & Business Processes & 185 & $74.60 \%$ \\
\hline & IT Development & 198 & $79.84 \%$ \\
\hline & IT Maintenance & 215 & $86.69 \%$ \\
\hline
\end{tabular}

Client Contract Portfolio

\begin{tabular}{|c|c|c|c|}
\hline \multirow{7}{*}{$\begin{array}{c}\text { Client Contract } \\
\text { Portfolio }\end{array}$} & Fixed-Price, Time and Materials \& Joint Venture & 20 & $8.06 \%$ \\
\hline & Fixed-Price \& Time and Materials & 73 & $29.43 \%$ \\
\hline & Fixed-Price \& Joint Venture & 31 & $12.50 \%$ \\
\hline & Time and Materials \& Joint Venture & 0 & $0.00 \%$ \\
\hline & Fixed-Price & 106 & $42.74 \%$ \\
\hline & Time and Materials & 14 & $5.64 \%$ \\
\hline & Joint Venture & 4 & $1.61 \%$ \\
\hline \multicolumn{4}{|c|}{ Description of the Respondent } \\
\hline \multirow{5}{*}{$\begin{array}{l}\text { Decision-Making } \\
\text { Authority of } \\
\text { Respondent* }\end{array}$} & & Frequency & Percentage \\
\hline & I represent the function at the executive level & 101 & $40.73 \%$ \\
\hline & I have global responsibility for the function & 184 & $74.19 \%$ \\
\hline & I have national responsibility for the function & 96 & $38.71 \%$ \\
\hline & $\begin{array}{l}\text { I am responsible for the function of a business unit } \\
\text { within the organization }\end{array}$ & 83 & $33.47 \%$ \\
\hline
\end{tabular}

* These items were not mutually exclusive; hence the total is greater than $100 \%$. 


\section{Measurement}

This study used previously validated scales from the literature, but since the scales were oriented towards intra-organizational processes, they were adapted to fit outsourcing arrangements. Appendix 1 provides the actual wording of the questions used in the survey.

\section{Dependent Variable}

Strategic Innovation Through Outsourcing ${ }^{5}$ : We measured strategic innovation using the scale developed by Jansen et al. (2006) $(\alpha=.848)$ (See Appendix 1 for the exact items). Answers to each item were anchored at $1=$ strongly disagree and $5=$ strongly agree. This scale is designed to measure the extent to which organizations pursued strategic (radical) innovations. We adapted this measure to incorporate strategic innovation with outsourcing partners rather than solely internal processes.

\section{Independent Variable}

The Quality of Client-Supplier Relationships $(\alpha=.823)$ was measured using a five-item scale adapted from Jaworski and Kohli (1993) (See Appendix 1 for the exact items asked) in order to assess the respondents' perceived quality of the relationships between the firm and its suppliers. Each item was anchored between $1=$ strongly disagree to $5=$ strongly agree. The scale was developed to measure the extent to which employees were networked to various other levels of the hierarchy. This scale was used in other studies (e.g. Jansen et al. 2006). We have adapted the measure to include cross-boundary connections between the client and supplier firms.

\footnotetext{
${ }^{5}$ Since there is very limited literature on strategic innovation in the context of IT and business process outsourcing, there were no previous studies that used an operational measure of strategic innovation through outsourcing in IS literature. Comparing how Weeks and Feeny (2008) define strategic innovation (included earlier in the paper) with the established definitions from the innovation literature where radical/exploratory innovations are considered to result in new products and/or service lines (Droege et al. 2009), entering new markets (Berry et al. 2006) or introducing new distribution channels (Jansen et al. 2006), we have concluded that "strategic innovation" in the IS outsourcing context is in line with what is viewed as radical or exploratory innovations. Therefore the existing measure of exploratory innovation was adopted.
} 
The five items measuring the perceived quality of the client-supplier relationships, as well as the six items measuring strategic innovation, were put through factor analyses using Promax rotation and Kaiser normalization in order to evaluate the internal and discriminant validity of the variables. The results displayed in Table 2 show two distinct factors. One factor represents strategic innovation, and the other represents the perceived quality of the client-supplier relationships. Each of the obtained variables reflects the average of the mean item values. 
Table 2: Factor analysis of components in analysis

\begin{tabular}{|c|c|c|c|c|}
\hline Items & $\begin{array}{l}\text { Cronbach's } \\
\text { Alphas }\end{array}$ & \multicolumn{2}{|c|}{ Pattern Matrix } & $\begin{array}{l}\% \text { of total } \\
\text { variance } \\
\text { explained }\end{array}$ \\
\hline We have invented new products and/or services working with 3rd parties. & \multirow{6}{*}{0.848} & 0.681 & & \multirow{6}{*}{40.56} \\
\hline $\begin{array}{l}\text { We experiment with new products and services in our existing market } \\
\text { through work with 3rd parties. }\end{array}$ & & 0.731 & & \\
\hline $\begin{array}{l}\text { Our organization accepts demands from clients that go beyond existing } \\
\text { products and services. }\end{array}$ & & 0.715 & & \\
\hline $\begin{array}{l}\text { We commercialize products and services that are completely new to our } \\
\text { organization through work with 3rd parties. }\end{array}$ & & 0.754 & & \\
\hline $\begin{array}{l}\text { We frequently utilize new opportunities in new markets through work with } \\
\text { 3rd parties. }\end{array}$ & & 0.850 & & \\
\hline $\begin{array}{l}\text { Our organization is exploring opportunities to use new distribution channels } \\
\text { to deliver products and services through work with 3rd parties. }\end{array}$ & & 0.675 & & \\
\hline $\begin{array}{l}\text { In our organization, there is ample opportunity for informal conversation } \\
\text { among our staff and 3rd party employees that are based on our premises. }\end{array}$ & \multirow{5}{*}{0.823} & & 0.714 & \multirow{5}{*}{18.45} \\
\hline $\begin{array}{l}\text { In our organization, our employees and 3rd party staff feel comfortable } \\
\text { approaching each other when the need arises. }\end{array}$ & & & 0.756 & \\
\hline $\begin{array}{l}\text { Managers discourage employees discussing work-related matters with those } \\
\text { who are not immediate superiors.** }\end{array}$ & & & 0.626 & \\
\hline $\begin{array}{l}\text { People involved in the outsourcing relationship are quite accessible to each } \\
\text { other (regardless of whether they represent client or supplier side). }\end{array}$ & & & 0.815 & \\
\hline $\begin{array}{l}\text { In our outsourcing organization, it is easy to talk with virtually anyone you } \\
\text { need to, regardless of rank, position or organization to which he/she } \\
\text { belongs. }\end{array}$ & & & 0.911 & \\
\hline
\end{tabular}

Notes: $\mathrm{N}=248 ; * *$ Reversed item.

All items were measured on a five-point scale, anchored by $1=$ strongly disagree and $5=$ strongly agree.

Extraction Method: Principal Component Analysis

Rotation Method: Promax with Kaiser Normalization

Rotation converged in 11 iterations

Scores under .37 are not displayed 


\section{Moderating Variable}

Type of contract: In order to test how different contractual arrangements influence the likelihood of achieving strategic innovation, we included three major types of contracts discussed in the literature that client organizations used with their outsourcing suppliers. Respondents were asked to indicate of the following contracts which type they have used with their suppliers: fixed-price (this included fixed fee for specified service and ticket-based contracts), time and materials or joint venture (see Appendix 1 for the exact item). Our moderating variable included all combinations of contract types used by the firms, which resulted in three categories of client contracts portfolios: $8.06 \%$ used a combination of fixed-price, time and materials and joint ventures; $29.43 \%$ used a combination of fixed-price and time and materials; $12.50 \%$ used a combination of fixed-price and joint ventures ${ }^{6,7}$; and three categories of stand-alone contracts: 42.74\% used just fixed-price; 5.64\% used just time and materials and 1.61\% used just joint ventures.

\section{Control Variables}

In the empirical study, we controlled for possible confounding effects by including various relevant control variables ${ }^{8}$. Three types of outsourcing arrangements were considered: business processes, IT development and IT application maintenance ${ }^{9}$. Of the types of outsourcing used, $74.60 \%$ of the

\footnotetext{
${ }^{6}$ There were no events reported for the combination of time and material and joint venture in our sample, as reported in Table 1.

${ }^{7}$ The data do not distinguish whether a client contract portfolio was used with a single or more suppliers. We highlight this shortcoming in the Limitations and Future Research section.

${ }^{8}$ We attempted additional controls including industry, country and size of the company, but none of them had a significant effect on the outcomes; in order to avoid over-saturating the regression model we do not include them in further analysis.

${ }^{9}$ In line with IS outsourcing literature, we have distinguished between IT and business process outsourcing (Lacity et al. 2011, Lacity et al. 2009; Mani et al. 2010). IT outsourcing (ITO) is defined as the sourcing of Information Technology services through an external third party (Lacity et al. 2011). Business process outsourcing (BPO) refers to the delegation of one or more Information Technology enabled business processes to an external service provider (Mani et al. 2010: 39). While ITO and BPO share many common attributes, such as the reliance on Information Technology solutions, there are some important differences between these two forms that have implications for the present study. From a client perspective, the main drivers of ITO are the ability to focus on core competencies of the firm and achieve reduction in costs. BPO, on the other hand, offers numerous objectives ranging from cost reductions to innovation and business transformation (Mani et al. 2010). It flows from this that client firms expect innovation to be delivered in the case of BPO. At the same time, ITO consists of at least two different components: IT development and application maintenance (e.g. Gopal and Sivaramakrishnan 2008; Gopal et al. 2003). IT development implies opportunities to innovate while application maintenance is traditionally perceived as less likely to lead to innovation.
} 
respondents indicated they outsourced business processes, $79.84 \%$ outsourced IT development and 86.69\% indicated that they outsourced IT application maintenance. Table 3 includes the means, standard deviations and correlations of all variables. 
Table 3: Means, standard deviations and correlations

\begin{tabular}{|c|c|c|c|c|c|c|c|c|c|c|c|c|}
\hline & Mean & $\begin{array}{l}\text { Std. } \\
\text { Dev. }\end{array}$ & 1 & 2 & 3 & 4 & 5 & 6 & 7 & 8 & 9 & 10 \\
\hline 1. Strategic Innovation & 3.27 & 0.86 & - & & & & & & & & & \\
\hline 2. Business Processes & 0.74 & 0.44 & -0.07 & - & & & & & & & & \\
\hline 3. IT Development & 0.80 & 0.40 & $-0.16^{* *}$ & $-0.29 * *$ & - & & & & & & & \\
\hline 4. IT Application Maintenance & 0.87 & 0.33 & 0.05 & 0.10 & $-0.19 * *$ & - & & & & & & \\
\hline $\begin{array}{l}\text { 5. Quality of Client-Supplier } \\
\text { Relationships }\end{array}$ & 3.38 & 0.82 & $0.52 * *$ & 0.02 & $0.33^{* *}$ & -0.01 & - & & & & & \\
\hline $\begin{array}{l}\text { 6. Fixed-Price, Time and Materials } \\
\text { \& Joint Venture }\end{array}$ & 0.08 & 0.27 & 0.06 & 0.07 & 0.03 & -0.08 & 0.04 & - & & & & \\
\hline 7. Fixed-Price \& Time and Materials & 0.29 & 0.45 & 0.06 & 0.01 & 0.08 & -0.09 & 0.03 & $-0.18 * *$ & - & & & \\
\hline 8. Fixed-Price \& Joint Venture & 0.13 & 0.33 & 0.00 & 0.08 & -0.04 & 0.10 & 0.03 & -0.11 & $-0.24 * *$ & - & & \\
\hline 9. Fixed-Price & 0.43 & 0.21 & -0.05 & 0.05 & 0.02 & -0.03 & 0.02 & -0.06 & $-0.14^{*}$ & -0.08 & - & \\
\hline 10. Time and Materials & 0.06 & 0.50 & -0.08 & -0.06 & -0.12 & 0.04 & -0.08 & $-0.25 * *$ & $-0.55^{* *}$ & $-0.32 * *$ & $-0.19 * *$ & - \\
\hline 11. Joint Venture & 0.02 & 0.11 & 0.03 & 0.07 & 0.06 & 0.04 & 0.09 & -0.03 & -0.07 & -0.04 & -0.03 & -0.10 \\
\hline
\end{tabular}

Note: $\mathrm{n}=248 .{ }^{*} \mathrm{p}<.05, * * \mathrm{p}<.01$

The value for the means for dichotomous variables represents the percentage of the sample in that category (variables 6-11 are dichotomous, 1 meaning a firm uses that type(s) of contract(s), and 0 meaning the firm does not use that type(s) of contract(s)) 


\section{Common Methods Variance}

In order to test for common methods variance (CMV) we conducted Harman's single-factor test (Podsakoff et al. 2003). Our results did not indicate common methods bias was high as more than one factor emerged to explain the variance in our analysis. In addition, no one factor accounted for the majority of covariance among the measures, meeting both of the criteria set forth by Podsakoff et al. (2003) for determining if a detrimental level of common method bias exists. We also conducted a second test to examine a control for the effects of an unmeasured latent method factor. In this test, only three of the paths from CMV to single-indicator constructs were significant, indicating a small amount of CMV.

\section{ANALYSIS AND RESULTS}

After assessing measurement properties and CMV, we tested our hypotheses regarding the effects of the quality of the client-supplier relationships on strategic innovation by estimating a series of hierarchical ordinary least squares linear regressions. Table 4 presents the results from these regressions. Model 1 includes just the control variables. Model 2 adds the effect of the quality of the client-supplier relationships. Model 3 adds the direct effects for the moderating variables. Finally Model 4 adds the interaction effects between the quality of the client-supplier relationships and the type of contract or client contract portfolio used in the relationships. To estimate these effects we used the PROCESS macro for SPSS (Hayes 2013) and tested the effects for statistical significance using 95\% bootstrapped confidence intervals based on 1000 samples to reduce bias (Hayes 2013). 
Table 4: Hierarchical OLS linear regression predicting strategic innovation

\begin{tabular}{|c|c|c|c|c|c|c|c|c|c|c|}
\hline & \multicolumn{2}{|c|}{ Model 1} & \multicolumn{2}{|r|}{ Model 2} & \multicolumn{3}{|c|}{ Model 3} & \multicolumn{3}{|c|}{ Model 4} \\
\hline & $\mathrm{B}$ & Std. Error & $\mathrm{B}$ & Std. Error & $\mathrm{B}$ & & Std. Error & $\mathrm{B}$ & & Std. Error \\
\hline Outsource Business Processes & -0.02 & 0.12 & -0.14 & 0.10 & -0.14 & & 0.11 & -0.16 & & 0.11 \\
\hline Outsource IT Development & $0.35 *$ & 0.13 & -0.04 & 0.12 & -0.05 & & 0.12 & -0.05 & & 0.12 \\
\hline Outsource IT Maintenance & 0.23 & 0.15 & 0.16 & 0.13 & 0.17 & & 0.14 & 0.17 & & 0.14 \\
\hline Quality of Client-Supplier Relationships & & & 0.50 & 0.06 & 0.51 & $* *$ & 0.06 & & & \\
\hline Fixed-Price, Time and Materials \& Joint Venture & & & & & 0.06 & * & 0.03 & & & \\
\hline Fixed-Price \& Time and Materials & & & & & -0.03 & & 0.26 & & & \\
\hline Fixed-Price \& Joint Venture & & & & & -0.12 & & 0.28 & & & \\
\hline Fixed-Price & & & & & -0.27 & & 0.32 & & & \\
\hline Time and Materials & & & & & -0.12 & & 0.26 & & & \\
\hline Joint Venture & & & & & 0.19 & & 0.47 & & & \\
\hline Fixed-Price, Time and Materials \& Joint Venture X Quality of Client-Suppl & ier Relati & onships & & & & & & 0.32 & * & 0.15 \\
\hline Fixed-Price \& Time and Materials X Quality of Client-Supplier Relationshir & & & & & & & & -0.62 & & 0.45 \\
\hline Fixed-Price \& Joint Venture X Quality of Client-Supplier Relationships & & & & & & & & 0.68 & $*$ & 0.27 \\
\hline Fixed-Price X Quality of Client-Supplier Relationships & & & & & & & & -0.89 & & 0.52 \\
\hline Time and Materials X Quality of Client-Supplier Relationships & & & & & & & & -0.63 & & 0.45 \\
\hline Joint Venture X Quality of the Client-Supplier Relationships & & & & & & & & 0.38 & * & 0.12 \\
\hline Intercept & 2.89 & 0.22 & 1.67 & 0.24 & 2.89 & & 0.22 & 1.87 & & 0.28 \\
\hline $\mathrm{R} 2$ & & 04 & & 0.28 & & 0.30 & & & 0.32 & \\
\hline$\Delta \mathrm{R}^{2}$ & & & & 0.25 & & 0.02 & & & 0.02 & \\
\hline
\end{tabular}

Note: $\mathrm{n}=248 .{ }^{*} \mathrm{p}<.05,{ }^{* *} \mathrm{p}<.01$ 
In Model 1, we saw the effects of the control variables. There was not a significant effect for outsourcing business processes on strategic innovation. There was a positive and significant effect for outsourcing IT development on strategic innovation $(\mathrm{B}=0.35, \mathrm{p}<0.05)$. Those firms that indicated they outsourced IT development reported higher levels of strategic innovation with their outsourcing partners. There was not a significant effect for outsourcing IT application maintenance on strategic innovation.

In Model 2 we added the effect of the quality of the client-supplier relationships to Model 1. There was a positive and significant effect of the quality of the client-supplier relationships on strategic innovation (B $=0.50, \mathrm{p}<0.01$ ), supporting hypothesis 1 . This suggested that higher quality relationships between the client firm and its suppliers are likely to deliver strategic innovation.

In Model 4 we tested the proposed moderation effects in hypothesis 2, which argue that a stand-alone contract and any client contract portfolio will moderate the effect of the quality of client-supplier relationships on strategic innovation (summarized in Table 5). In order to test the moderation effects, we estimated a "main effect” model (Model 3) with a moderating effect model (Model 4) (Carte and Russell 2003) and meeting nine conditions that no errors have been made. Our analysis concluded that no errors of commission were made. The interaction terms were calculated by multiplying the moderator (client contract portfolio that combines several contracts or stand-alone contract) by the predictor variable (quality of client-supplier relationships). The moderating effects model included these variables, but the main effect model did not. The effect for the moderation of using a client contract portfolio that included all three contract types on the influence of the quality of the client-supplier relationships on strategic innovation was positive and significant $(\mathrm{B}=0.32, \mathrm{p}<0.05)$. The effect for the moderation of client contract portfolio that combined fixed-price and time and materials contracts on the influence of the quality of the client-supplier relationships on strategic innovation was not significant $(B=-0.62, p=$ n.s. $)$. The effect for the moderation of a client contract portfolio comprised of fixed-price and joint venture contracts on the influence of the quality of the client-supplier relationships on strategic innovation was 
positive and significant $(\mathrm{B}=0.68, \mathrm{p}=0.05)$. The effect for the moderation of fixed-price contracts on the influence of the quality of the client-supplier relationships on strategic innovation was not significant $(\mathrm{B}=$ $-0.89, \mathrm{p}=$ n.s.). The effect for the moderation of time and materials contracts on the influence of the quality of the client-supplier relationships on strategic innovation was not significant $(B=-0.63, p=$ n.s. $)$. The effect for the moderation of joint venture contracts on the influence of the quality of the clientsupplier relationships on strategic innovation was positive and significant $(B=0.38, p=0.05)$. Overall, our results consistently show that the use of joint venture contracts (either as a stand-alone contract or as part of a client contract portfolio) positively moderate the effect of the quality of client-supplier relationships on strategic innovation. The $\mathrm{R}^{2}$ of the main effect model is .28 , and the $\mathrm{R}^{2}$ for the moderation model is .32. The increase in $\mathrm{R}^{2}$ due to the addition of the interactions of the combinations of outsourcing arrangements and the quality of the client-supplier relationships is statistically significant. In order to further test the robustness of our results, we calculated the effect size formula suggested by Cohen (1988): $\mathrm{F}^{2}=\left[\mathrm{R}^{2}\right.$ (moderation model) $-\mathrm{R}^{2}$ (main effect model)]/[1- $\mathrm{R}^{2}$ (main effect model)]. We obtained an effect size $F^{2}$ of 0.04 . Then, we multiplied $F^{2}$ by (n-k-1), where $n$ equals sample size, and $k$ equals the number of independent variables. This enabled us to conduct a pseudo F-test for the change in $\mathrm{R}^{2}$ with 1 and n-k degrees of freedom (Mathieson et al. 2001). The result of the pseudo F-test was 10.27 $(\mathrm{p}<.05)$. Based on the values provided by Cohen (1988), an effect size of 0.02 is small, 0.15 is moderate, and 0.35 is large; therefore, we can conclude that the effect is small, yet significant. To further illustrate the impact of the moderations, we also charted the predicted values of strategic innovation when the moderations are present (see Figures 2.1 and 2.2). Here it is visually apparent that the use of joint venture contracts, either alone or in combination with other contract types, magnifies the effect of the quality of client-supplier relationships. A test of the differences in slopes ${ }^{10}$ indicates that there is a significant difference between the slopes of the interaction of the quality of client-supplier relationships and the client contract portfolios $(\mathrm{F}(5,241)=5.31, \mathrm{p}<.05)$.

\footnotetext{
${ }^{10}$ We divided interaction effects between two figures: Figure 2.1 depicts predicted values of strategic innovation for stand-alone contracts and Figure 2.2 depicts predicted values of strategic innovation for the client contract portfolios. The test of the differences in slopes was run on all six interactions, combined.
} 
Table 5: Summary of Results

\begin{tabular}{|l|l|l|}
\hline Hyposis & Support/Reject \\
\hline $\mathbf{H 1}$ & $\begin{array}{l}\text { Positive relationship between the quality of client-supplier } \\
\text { relationships and the likelihood of achieving strategic innovation }\end{array}$ & Supported \\
\hline $\mathbf{H 2}$ & $\begin{array}{l}\text { The influence of stand-alone contracts and client contract portfolios } \\
\text { on the positive effect of the quality of client-supplier relationships on } \\
\text { the likelihood of achieving strategic innovation: } \\
\text { - Fixed-Price } \\
\text { - Time and Materials } \\
\text { - Joint Venture } \\
\text { - Fixed-Price, Time and Materials \& Joint Venture } \\
\text { - Fixed-Price \& Time and Materials } \\
\text { - Fixed-Price \& Joint Venture }\end{array}$ & $\begin{array}{l}\text { Rejected } \\
\text { Rejected } \\
\text { Supported (+) } \\
\text { Supported (+) } \\
\text { Rejected } \\
\text { Supported (+) }\end{array}$ \\
\hline
\end{tabular}

Figure 2.1: Predicted values of strategic innovation for contract types

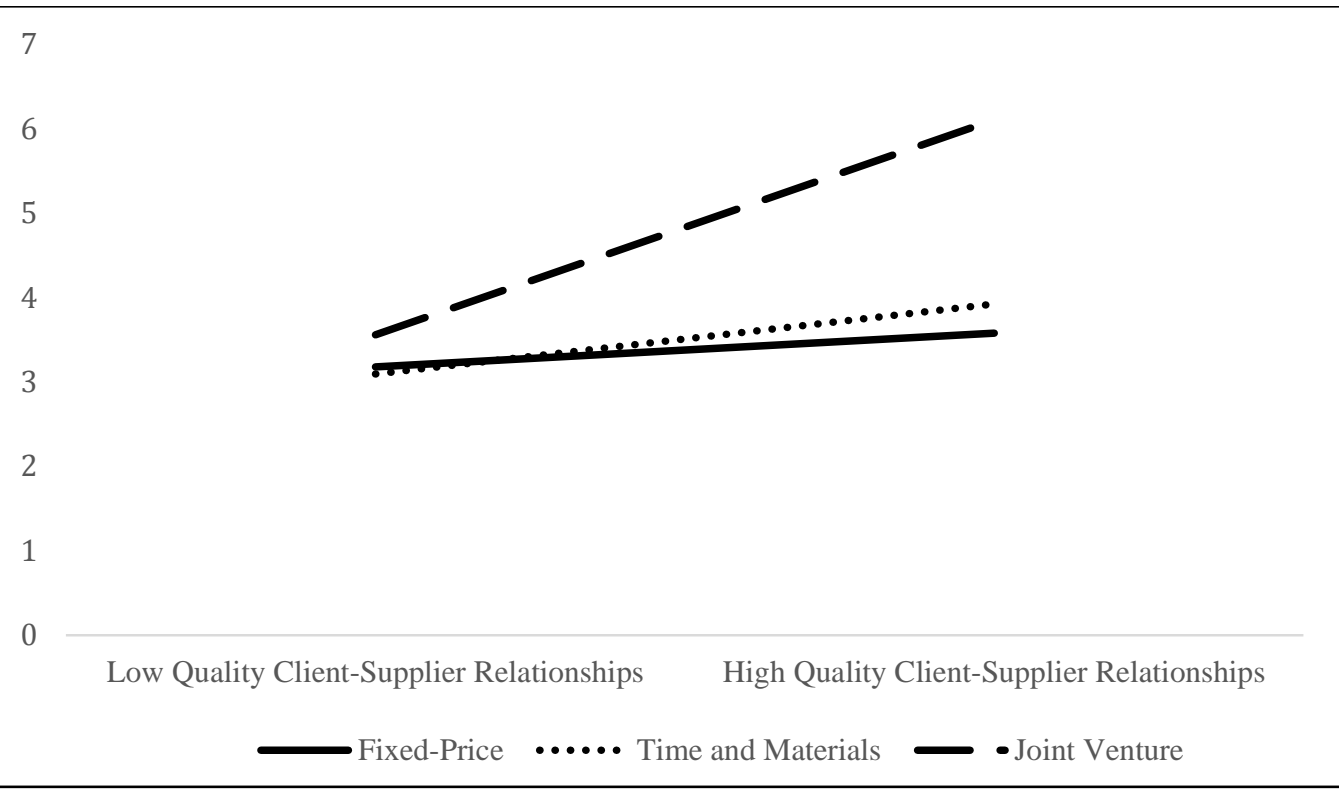


Figure 2.2: Predicted values of strategic innovation for client contract portfolios

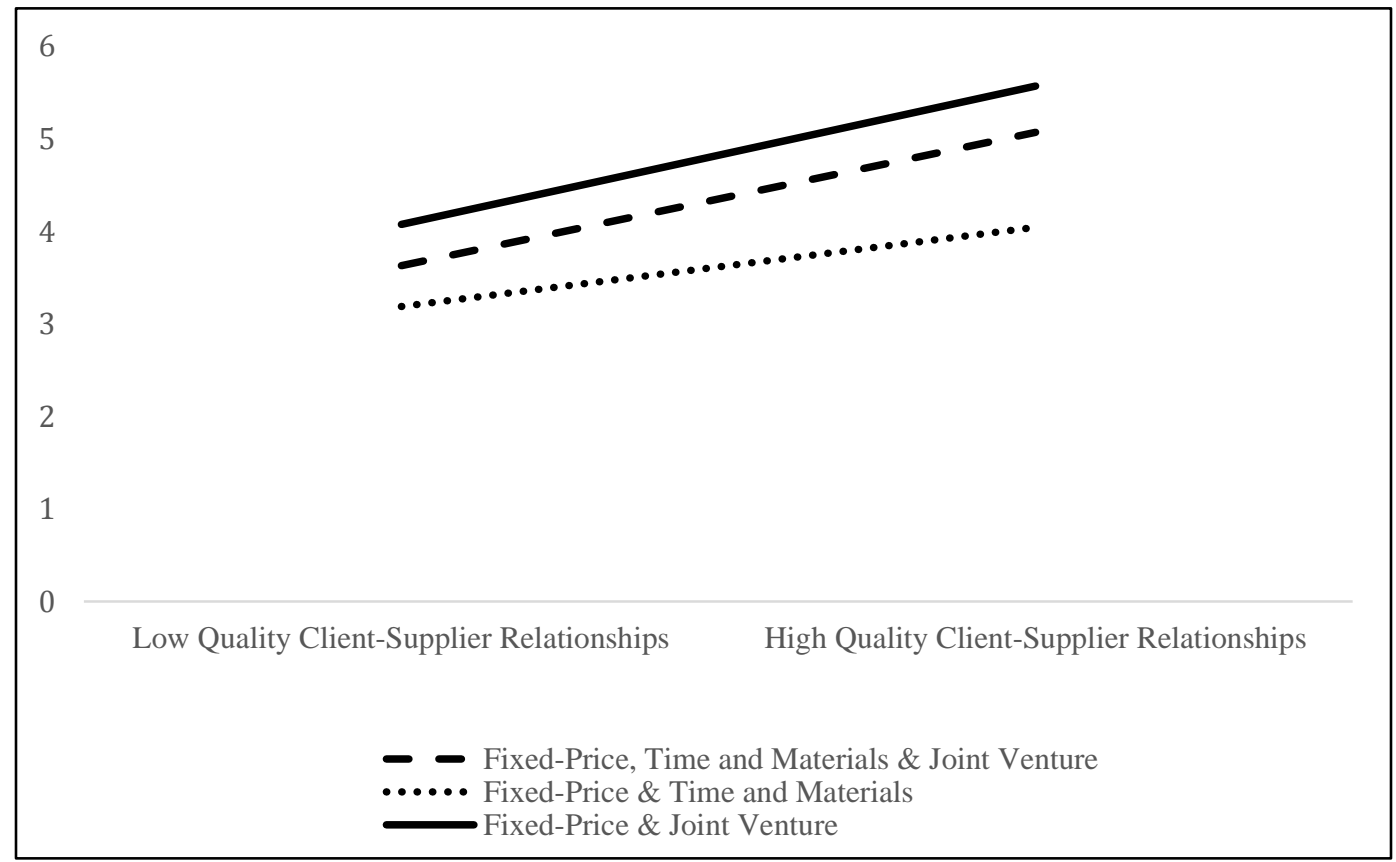

\section{DISCUSSION AND CONTRIBUTIONS}

In this study we sought to examine the effect of relational and contractual governance on the ability to achieve strategic supplier-led innovation through outsourcing. We were motivated by several IS outsourcing studies that discussed innovation as a possible outcome of an outsourcing engagement and suggested that a high-quality relational governance may improve opportunities to achieve strategic supplier-led innovation. While such studies supported their arguments by relying on empirical evidence in the form of case studies of innovations that go beyond operational and business process improvements and address strategic challenges (Weeks and Feeny 2008; Whitley and Willcocks 2011; Lacity and Willcocks 2014), our study aimed to model and test the effect of relational and contractual governance on the likelihood of achieving strategic innovation.

The results of this study have confirmed that high-quality client-supplier relationships positively affect the ability to achieve strategic innovation through outsourcing engagements. In this regard, high-quality client-supplier relationships facilitate the supplier's ability to learn about the client's business (Zaheer and 
Venkatraman 1995; Kishore et al. 2003), thus assisting in developing solutions that go beyond IT operational or business process innovation to affect services delivered to existing clients or even developing new markets (Weeks and Feeny 2008), similar to the earlier example we provided above about IBM engaging in strategic innovation for Novartis. Further, high-quality client-supplier relationships provide advantages to the parties by mitigating risk for the risk-exposed party through the use of relational flexibility that promotes adjustments in the contract to meet expectations of all parties (Gopal and Koka 2012).

Motivated by extant literature that discusses complementarity between relational and contractual governance in improving outsourcing performance (e.g. Huber et al. 2013), we modelled and tested the interactions between contractual and relational governance as affecting strategic supplier-led innovation. In particular, we modelled and tested the effect of three contract types as well as explored the influence of different contract types and client contract portfolios on the positive effect of the quality of client-supplier relationships on strategic innovation. Our results show that when used as a stand-alone contract, fixedprice and time and materials contracts do not magnify or weaken the positive effect of the quality of the relationships on the ability to achieve strategic innovation through outsourcing. Our results also demonstrate that using a joint venture contract magnifies the positive effect of the quality of the clientsupplier relationships on the ability to achieve strategic innovation. The moderation effect of a standalone joint venture contract on the positive effect of the quality of the relationships on the ability to achieve strategic innovation is positive and significant; however, we refrain from discussing these results because of the small number of firms in the sample.

Results also show that a client contract portfolio that combines fixed-price and time and materials contracts does not magnify or weaken the positive effect of client-supplier relationships on strategic innovation. One explanation for these findings is that, from the client's perspective, there are little or no interactions between the fixed-price and time and materials outsourcing engagements to suggest that they 
would enhance the positive effect of the relationships between the client and its suppliers to result in strategic innovation.

Here we posit the following question: why does a joint venture contract or a combination of a joint venture contract with either a fixed-price or time and materials contract magnify the positive effect of the relationships on the possibility to achieve strategic innovation? We have argued that a contract (standalone or included in a client contract portfolio) may magnify the effect of the quality of the client-supplier relationships should the contract help deflate the risk of opportunism on behalf of either the client firm or the supplier. A joint venture contract (as a stand-alone or alongside a fixed-price or time and materials contract as part of client contract portfolio scenario 1) presents the parties with a similar level of risk as both client firm and supplier contribute capital and people to the venture, thus weakening the materialization of opportunism for either side and stimulating the parties to work towards common business goals (Overby 2012). Such partnership schemes, as part of the client contract portfolio, also motivate the parties to collaborate as the potential return from the investment can be achieved only if the venture is successful (DiRomualdo and Gurbaxani 1998). Based on our results, we suggest that when using the gainsharing model alongside either fixed-price or time and materials contracts as part of client contract portfolio scenario 1 , the client and supplier realize the potential of benefiting from the joint venture, rather than just safeguarding against an opportunistic behaviour of the other party (Gopal and Koka 2012). This explanation is in line with the assertion that strategic and radical innovations are likely to be found in inter-organizational relationships and networks where firms seek access to resources and capabilities that cannot be found internally (Dewar and Dutton 1986; Henderson and Clark 1990), also known as complementary assets (Teece 1986). For example, inter-organizational networks can facilitate the development of the joint research capability required for strategic innovation, which is greater than the research capability that the client firm can develop on its own (Powell 1996; Hoecht and Trott 2006). A joint research capability may still lead to a continuous bargaining process between the client and supplier about the appropriation of the value created (Mol 2005); however, the presence of a contractual 
mechanism in the form of a gainsharing scheme, as part of the client contract portfolio, is likely to increase transparency regarding commitment and profit sharing involved in such a setting.

Explaining the positive effect of a joint venture contract alongside fixed-price and time and materials contracts as part of client contract portfolio scenario 2 is challenging. One possible explanation is that the presence of a joint venture contract in such a client contract portfolio stimulates the client firm to share the learning gained in the joint venture outsourcing engagement with other outsourcing engagements within the portfolio in order to improve performance and strengthen relationships with its suppliers. We therefore suggest that future research should examine the relationship between contract types and intraorganizational learning (across different outsourcing engagements) within the client firm's contract portfolio.

Further, the unsupported assumptions regarding the effect of stand-alone fixed-price and time and materials contracts on relational governance requires further explanation: Indeed, past studies suggested that in fixed-price contracts the supplier is exposed to the risk of not meeting its profitability targets if the task at hand is undefined, in particular as suppliers tend to deploy highly qualified personnel in fixedprice contracts (Gopal and Sivaramakrishnan 2008; Gopal and Koka 2010). Mitigating this risk should have been through the use of relational flexibility in which the supplier would have proposed on-going adjustments in the contract; however, this would be at the risk of negatively affecting the quality of the relationship with the client (Gopal and Koka 2012). Time and materials contracts may have resulted in unsatisfactory quality as a result of the supplier staffing the project with less qualified personnel thus exercising opportunism over the client. At the same time, the supplier is likely to exploit the opportunity to increase revenue through the engagement in strategic innovation and therefore is likely to refrain from opportunistic behaviour. As our results did not support either of these behaviours we may consider the following alternative explanations. In the first alternative explanation we argue that since our survey involved large firms engaging in large outsourcing contracts often over many years, it is possible that the parties have developed strong relational flexibility that allows them to cope with on-going adjustments to 
a fixed-price contract despite the higher uncertainty involved. In the second alternative explanation we posit that the supplier may perceive some of the risks as opportunities to further engage in product and service development projects for the client, which would translate into future business opportunities. As a result, the supplier will focus on other outcomes that go beyond improving the client's business performance, responding to the client's emerging issues. In such a case, the supplier is likely to demonstrate "good will” in resolving unforeseen or unaccounted for activities.

\section{Theoretical Implications}

To our knowledge, this is the first study that investigates strategic innovation as a dependent variable of outsourcing. In this regard, our study extends past studies that examined the effect of relational and contractual governance on outsourcing performance in two ways. First, results of our study suggest that outsourcing outcomes (typically viewed as business and process performance improvements (Lacity et al. 2011)) could include strategic innovation, which opens possibilities for future studies to model and measure strategic innovation as part of outsourcing performance. Second, our study reveals that clientsupplier relationships play a major role in facilitating strategic innovation through outsourcing. While research has argued that relational and contractual governance may act as complements rather than substitutes (Kishore et al. 2003; Koh et al. 2004; Moon et al. 2010), our analysis suggests that such interactions between these two governance approaches are likely to happen in the case of strategic innovation under certain conditions such as when joint venture or other gainsharing schemes are part of the client contract portfolio and less likely to happen in the case of stand-alone fixed-price and time and materials contracts (Gopal and Koka 2012).

\section{Practical Implications}

There are some practical implications that surface from this study. Our study supports past observations that client firms seeking strategic innovation through outsourcing should first and foremost invest in relational governance. Indeed, useful practices for innovation through outsourcing have been widely 
reported by Lacity and Willcocks (2014) which include leadership pairs from client and supplier, trust building steps and modes of operation that support collaboration and openness. Managers should also consider the type of contracting when seeking strategic innovation. While our analysis shows that fixedprice contracts are widely used in outsourcing deals, there is now growing evidence that clients and suppliers use contracts with joint venture schemes as a way to incentivize parties to engage in high-risk strategic innovation initiatives (Overby 2012; Halvey and Melby 2005). Last but not least, managers need to consider strategic innovation through outsourcing at the outset of contracting, i.e. as part of the strategic intent of the outsourcing act (Whitley and Willcocks 2011). Indeed, a study by Leimeister et al. (2008) shows variation in behaviours between firms that seek and those that do not seek innovation from their IT outsourcing engagements, highlighting the importance of strategic intent as the first step in pursuing innovation through outsourcing.

\section{Limitations and Future Research}

Finally, the analysis presented in this paper is subject to several limitations. First, we have used three types of contracts which do not necessarily represent the complete range of contracts applied by firms in their outsourcing engagements. Future research should consider extending the range of contract types used in outsourcing engagements to include outcome-based contracts, and looking into different alternative arrangements that fit under the broad category of fixed-price contracts, such as large work package fixed-fee and consumption-based contracts. Second, our sample is biased towards the European perception of strategic innovation through outsourcing which can be affected by the relative immaturity level of the European outsourcing market as compared with the USA market. We see an opportunity to conduct a similar study in the context of the USA outsourcing industry to compare with the results of this study. Third, our study hinted at the possibility that learning between outsourcing engagement teams may play a role in explaining the moderating effect of a client contract portfolio. As our study did not investigate the degree of interactions between the outsourcing engagement teams as part of a client contract portfolio, we propose that future research should broaden the range of factors considered to 
influence strategic innovation by including the degree of interactions and learning (Newell, 2004) achieved within a client contract portfolio. Last but not least, DiRomualdo and Gurbaxani (1998) found that clients need to match the type of ITO decision (business improvement, IS improvement, or commercialization) with the appropriate contract type. Our study did not consider the strategic intent of the client firm as our intention was to test senior managers' general perceptions regarding the link between outsourcing and strategic innovation. Future research could refine our results by including the strategic intent as a variable affecting the type of contract selected for outsourcing. 


\section{Appendix 1: Measures and Items}

The following text was included in the beginning of the questionnaire: "In this research questionnaire we are going to ask you about the outsourcing of IT and business processes to third-party providers. By outsourcing we mean business process outsourcing and technology outsourcing as opposed to facilities and service management.”

\section{Strategic Innovation*}

Based on Jansen et al. (2006)

We have invented new products and/or services working with 3rd parties.

We experiment with new products and services in our existing market through work with 3rd parties.

Our organization accepts demands from clients that go beyond existing products and services.

We commercialize products and services that are completely new to our organization through work with 3rd parties.

We frequently utilize new opportunities in new markets through work with 3rd parties.

Our organization is exploring opportunities to use new distribution channels to deliver products and services through work with 3rd parties.

\section{Quality of Client-Supplier Relationships}

Based on Jaworski and Kohli (1993)

In our organization, there is ample opportunity for informal conversation among our staff and 3rd party employees that are based on our premises.

In our organization, our employees and 3rd party staff feel comfortable approaching each other when the need arises.

Managers discourage employees discussing work-related matters with those who are not immediate superiors.**

People involved in the outsourcing relationship are quite accessible to each other (regardless of whether they represent client or supplier side). 
In our outsourcing organization, it is easy to talk with virtually anyone you need to, regardless of rank, position or organization to which he/she belongs.

\section{Contract Type}

What type of contracts do you use with your vendors? (You can select more than one type of contract)

Time and materials

Fixed-price (e.g. fixed fee for specified service and/or ticket-based contract)

Joint venture with profit sharing

*All items were measured on a five-point scale, anchored by $1=$ strongly disagree and $5=$ strongly agree.

** Reversed item. 


\section{REFERENCES}

Bajari, P. and Tadelis, S., 2001. Incentives Versus Transaction Costs: A Theory of Procurement Contracts. The RAND Journal of Economics 32 (3), 387-407.

Becheikh, N., Landry R. and Amara N., 2006. Lessons from Innovation Empirical Studies in the Manufacturing Sector: A Systematic Review of the Literature from 1993-2003. Technovation, 26 (5/6), 644-664.

Berry, L. L., Shankar, V., Turner-Parish, J., Cadwallader, S. and Dotzel, T., 2006. Creating New Markets Through Service Innovation. Sloan Management Review 47 (2), 56-63.

Carson, S. J., Madhok, A. and Wu, T., 2006. Uncertainty, opportunism, and governance: The effects of volatility and ambiguity on formal and relational contracting. Academy of Management Journal 49 (5), 1058-1077.

Carte, T. A. and Russell, C. J., 2003. In Pursuit of Moderation: Nine Common Errors and Their Solutions. MIS Quarterly 27 (3), 479-501.

Cohen, J., 1988. Statistical Power Analysis for the Behavioral Sciences. Lawrence Erlbaum Associates, New Jersey.

Dewar, R. D. and Dutton, J. E., 1986. The adoption of radical and incremental innovations: an empirical analysis. Management Science 32 (11), 1422-1433.

Dey, D., Fan, M. and Zhang, C., 2010. Design and Analysis of Contracts for Software Outsourcing. Information Systems Research 21 (1), 93-114.

Dibbern, J., Goles, T., Hirschheim, R. and Jayatilaka, B., 2004. Information Systems Outsourcing: A Survey and Analysis of the Literature. The DATA BASE for Advances in Information Systems 35 (4), 6-102.

Dibbern, J., Winkler, J. and Heinzl, A., 2008. Explaining Variations in Client Extra Costs Between Software Projects Offshored to India. MIS Quarterly 32 (2), 333-366.

DiRomualdo, A. and Gurbaxani, V., 1998. Strategic intent for IT outsourcing. Sloan Management Review 39 (4), 67-80.

Droege, H., Hildebrand, D. and Heras-Forcada, M. A., 2009. Innovation in services: present findings and future pathways. Journal of Service Management 20 (2), 131-155.

Dyer, J. H. and Nobeoka, K., 2000. Creating and managing a high-performance knowledge sharing network: the Toyota case. Strategic Management Journal 21 (3), 345-367.

Ettlie, J., Bridges, W. P. and O’Keefe, R. D., 1984. Organizational strategy and structural differences for radical versus incremental innovation. Management Science 30 (6), 682-695.

Gefen, D., Wyss, S. and Lichtenstein, Y., 2008. Business familiarity as risk mitigation in software developmentoutsourcing contracts. MIS Quaterly 32 (3), 531-551.

Goo, J. and Huang, C. D., 2008. Facilitating relational governance through service level agreements in IT outsourcing: An application of the commitment-trust theory. Decision Support Systems 46 (1), 216-232.

Goo, J., Huang, C. D. and Hart, P., 2008. A Path to Successful IT Outsourcing: Interaction Between Service-Level Agreements and Commitment. Decision Sciences 39 (3), 469-506.

Goo, J., Kishore, R., Rao, H. and Nam, K., 2009. The role of service level agreements in relational management of information technology outsourcing: An empirical study. MIS Quarterly 33 (1), 119-145. 
Gopal, A. and Koka, B., 2010. The Role of Contracts in Quality and Returns to Quality in Offshore Software Development. Decision Sciences 41 (3), 491-516.

Gopal, A. and Koka, B., 2012. The Asymmetric Benefits of Relational Flexibility: Evidence From Software Development Outsourcing. MIS Quarterly 36 (2), 553-576.

Gopal, A. and Sivaramakrishnan, K., 2008. On Vendor Preferences for Contract Types in Offshore Software Projects: The Case of Fixed Price vs. Time and Materials Contracts. Information Systems Research 19 (2), 202-220.

Gopal, A., Sivaramakrishnan, K., Krishnan, M. and Mukhopadhaya, T., 2003. Contracts in Offshore Software Development: An empirical analysis. Management Science 49 (12), 1671-1683.

Halvey, J.K. and Melby B.M., 2005. Information Technology Outsourcing Transcations: Process, Strategies and Contracts, John Wiley \& Sons, New Jersey.

Hayes, A. F. (2013). Introduction to mediation, moderation, and conditional process analysis. New York: The Guilford Press.

Henderson, R. M. and Clark, K. B., 1990. Architectural Innovation: The Reconfiguration of Existing Product Technologies and the Failure of Established Firms. Administrative Science Quarterly 35 (1), 9-30.

Hoecht, A. and Trott, P., 2006. Innovation risks of strategic outsourcing. Technovation 26 (5/6), 672-681.

Huber, T., Fischer, T., Dibbern, J. and Hirschheim, R., 2013. A Process Model of Complementarity and Substitution of Contractual and Relational Governance in IS Outsourcing. Journal of Management Information Systems 30 (3), 81-114.

Jansen, J. J. P., Van Den Bosch, F. A. J. and Volberda, H. W., 2006. Exploratory Innovation, Exploitative Innovation, and Performance: Effects of Organizational Antecedents and Environmental Moderators Management Science 52 (11), 1661-1674.

Jaworski, B. J. and Kohli, A. K., 1993. Market Orientation: Antecedents and Consequences. Journal of Marketing 57 (3), 53-70.

Kern, T., Willcocks, L. P. and van Heck, E., 2002. The Winner's Curse in IT Outsourcing: Strategies for Avoiding Relational Trauma. California Management Review 44 (2), 47-69.

Khan, N. and Fitzgerald, G., 2004. Dimensions of Offshore Outsourcing Business Models. Journal of Information Technology Cases and Applications 6 (3), 35-50.

Kishore, R., Rao, H. R., Nam, K., Rajagopalan, S. and Chaudhury, A., 2003. A relationship perspective on IT outsourcing. Communications of the ACM 46 (12), 86-92.

Koh, C., Ang, S. and Straub, D., 2004. IT Outsourcing Success: A Psychological Contracts Perspective. Information Systems Research 15 (4), 356-373.

Krishnan, M. S., Kriebel, C. H., Kerke, S. and Mukhopadhyay, T., 2000. An Empirical Analysis of Productivity and Quality in Software Products. Management Science 46 (6), 745-759.

Kumar, N., Stern, L. N. and Anderson, J. C., 1993. Conducting interorganizational research using key informants. Academy of Management Journal 36 (6), 1633-1651.

Lacity, M. C. and Willcocks, L. P., 2013. Beyond Cost Savings: Outsourcing Business Processes for Innovation. Sloan Management Review 54 (3), 63-69.

Lacity, M. C. and Hirschheim, R., 1993. The Information Systems Outsourcing Bandwagon: Look before you leap. Sloan Management Review 35 (1), 72-86. 
Lacity, M. C., Khan, S., Yan, A. and Willcocks, L. P., 2010. A review of the IT outsourcing empirical literature and future research directions. Journal of Information Technology 25 (4), 395-433.

Lacity, M. C., Khan, S., and Willcocks, L. P., 2009. A Review of the IT Outsourcing Literature: Insights for Practice. Journal of Strategic Information Systems 18 (3), 130-146.

Lacity, M. C., Solomon, S., Yan, A. and Willcocks, L. P., 2011. Business process outsourcing studies: a critical review and research directions. Journal of Information Technology 26 (4), 221-258.

Lacity, M. C. and Willcocks, L. P., 2014. Business Process Outsourcing and Dynamic Innovation. Strategic Outsourcing: An International Journal 7 (1), 66-92.

Lee, J. N., 2001. The Impact of Knowledge Sharing, Organizational Capability and Partnership Quality on IS Outsourcing Success. Information \& Management 38 (5), 323-335.

Lee, J. N. and Kim, Y. G., 1999. Effect of partnership quality on IS outsourcing success: conceptual framework and empirical validation. Journal of Management Information Systems 15 (4), 29-61.

Leimeister, S., Böhmann, T. and Krcmar, H., 2008. IS Outsourcing Governance in Innovation-Focused Relationships - an Empirical investigation. Proceedings of the European Conference on Information Systems, Galway.

Levina, N. and Vaast, E., 2008. Innovating or Doing as Told? Status Differences and Overlapping Boundaries in Offshore Collaboration. MIS Quarterly 32 (2), 307-332.

Lewin, A. Y., Massini, S. and Peeters, C., 2009. Why are companies offshoring innovation? The emerging global race for talent. Journal of International Business Studies 40 (6), 901-925.

Linder, J., 2004. Transformational Outsourcing. Sloan Management Review 45 (2), 52-58.

Linder, J. C., Jarvenpaa, S. and Davenport, T. H., 2003. Toward an Innovation Sourcing Strategy. MIT Sloan Management Review 44 (4), 43-49.

Loh, L. and Venkatraman, N., 1992. Diffusion of Information Technology Outsourcing: Influence Sources and the Kodak Effect. Information Systems Research 3 (4), 334-358.

Malhotra, A., Majchrzak, A., Carman, R. and Lott, V., 2001. Radical Innovation Without Collocation: A Case Study at Boeing-Rocketdyne. MIS Quarterly 25 (2), 229-249.

Mani, D., Barua, A. and Whinston, A., 2010. An Empirical Analysis of the Impact of Information Capabilities Design on Business Process Outsourcing Performance. MIS Quarterly 34 (1), 39-62.

Mathieson, K., Peacock, E. and Chin, W. W., 2001. Extending the technology acceptance model: The influence of perceived user resources. The DATA BASE for Advances in Information Systems 32 (3), 86-112.

McDermott, C. M. and O’Connor, G. C., 2002. Managing radical innovation: an overview of emergent strategy issues. Journal of Product Innovation Management 19 (6), 424-438.

Mol, M. J., 2005. Does being R\&D intensive still discourage outsourcing? Evidence from Dutch manufacturing. Research Policy 34 (4), 571-582.

Moon, J., Swar, B., Choe, Y. C., Chung, M. and Jung, G. H., 2010. Innovation in IT Outsourcing Relationships: Where is the Best Practice of IT Outsourcing in the Public Sector? Innovation: Management, Policy \& Practice 12 (2), 217-226.

Newell, S., 2004. Enhancing cross-project learning. Engineering Management Journal 16 (1), 12-20.

Oshri, I., Kotlarsky, J. and Willcocks, L. P., 2015. The Handbook of Global Outsourcing and Offshoring. $3^{\text {rd }}$ edition. Palgrave Macmillan, London. 
Overby, S., April $13^{\text {th }}$ 2012. 4 new IT outsourcing pricing models gain popularity, CIO Magazine, weblink: http://www.cio.com/article/2397240/outsourcing/4-new-it-outsourcing-pricing-modelsgain-popularity.html, last accessed February $27^{\text {th }} 2015$.

Podsakoff, P. M., MacKenzie, S. M., Lee, J. and Podsakoff, N. P., 2003. Common method variance in behavioral research: A critical review of the literature and recommended remedies. Journal of Applied Psychology 88 (5), 879-903.

Poppo, L. and Zenger, T., 2002. Do formal contracts and relational governance function as substitutes or complements? Strategic Management Journal 23 (8), 707-725.

Powell, W. W., 1996. Trust-Based Forms of Governance. In: Trust in Organizations: Frontiers of Theory and Research. Kramer R. M. and Tyler T.R. (Eds). Sage, Thousand Oaks, CA.

Quinn, J. B., 2000. Outsourcing innovation: the new engine of growth. Sloan Management Review 41 (4), $13-28$.

Quinn, J. B. and Hilmer, F., 1994. Strategic Outsourcing. Sloan Management Review 35 (4), 43-55.

Rottman, J. and Lacity, M. C., 2006. Proven Practices for Effectively Offshoring IT Work. Sloan Management Review 47 (3), 56-63.

Segars, A. H. and Grover, V., 1998. Strategic information systems planning success: An investigation of the construct and its measurement. MIS Quarterly 22 (2), 139-163.

Teece, D. J., 1986. Profiting from technological innovation: Implications for integration, collaboration, licensing and public policy. Research Policy 15 (6), 285-305.

Tiwana, A., 2010. Systems Development Ambidexterity: Explaining the Complementary and Substitutive Roles of Formal and Informal Controls. Journal of Management Information Systems 27 (2), 87126.

Tsai, W. and Ghoshal, S., 1998. Social Capital and Value Creation: The Role of Intrafirm Networks. Academy of Management Journal 41 (4), 464-476.

Weeks, M. R. and Feeny, D., 2008. Outsourcing: from cost management to innovation and business value. California Management Review 50 (4), 127-146.

Whitley, E. A. and Willcocks, L. P., 2011. Achieving Step-Change in Outsourcing Maturity: Toward Collaborative Innovation. MIS Quarterly Executive 10 (3), 95-107.

Willcocks, L. P. and Choi, J. C., 1995. Co-operative partnership and 'Total' IT Outsourcing: From contractual obligation to Strategic Alliance? European Management Journal 13 (1), 67-78.

Zaheer, A. and Venkatraman, N., 1995. Relational governance as an interorganizational strategy: An empirical test of the role of trust in economic exchange. Strategic Management Journal 16 (5), 373-392. 